\title{
COORDINATED IMPROVEMENT OF GRAIN YIELD AND PROTEIN CONTENT IN DRYLAND WHEAT BY SUBSOILING AND OPTIMUM PLANTING DENSITY
}

\author{
ZHANG, J. - KHAN, S. - SUN, M.* - GAO, Z. Q. - LIANG, Y. F. - YANG, Q. S. - ZHANG, H. Y. - \\ LI, N. N. \\ College of Agriculture, Shanxi Agriculture University \\ Taigu 030801, P.R.China \\ *Corresponding author \\ e-mail:sm_sunmin@126.com; phone: 0354-6287187; fax: 0354-6287187 \\ (Received $1^{\text {st }}$ Aug 2018; accepted $5^{\text {th }}$ Oct 2018)
}

\begin{abstract}
Subsoiling during fallow period is an important agronomic practice for storing soil moisture in dryland for winter wheat. Present study was designed to evaluate the effect of different planting density and tillage condition on nitrogen metabolizing enzymes, protein content, protein yield and grain yield of dryland wheat. Field experiment was carried out in Loess Plateau, Wenxi, Shanxi province, China from 2012 to 2014, using winter wheat cultivar Yunhan 20410. Subsoiling (SS) during fallow period or notillage (NT) was taken as main factor and planting density (LD, 190 plants $\mathrm{m}^{-2}, \mathrm{MD}, 260$ plants $\mathrm{m}^{-2}$, HD, 320 plants $\mathrm{m}^{-2}$ ) as subplot factors. Results showed that SS has significantly increased the tiller numbers. Furthermore, SS has increased the soil water content at sowing by $83 \mathrm{~mm}$ and $58 \mathrm{~mm}$, soil water at anthesis by $38 \mathrm{~mm}$ and $10 \mathrm{~mm}$, and grain yield by $26 \%-66 \%$ and $17 \%-34 \%$ in 2012-2013 and 2013-2014, respectively as compared to NT, whereas, gliadin, glutenin, albumin and total protein content of grain were decreased. Under SS, the soil water storage at anthesis in 0-300 $\mathrm{cm}$ soil layer was highest at LD and lowest at MD. The activities of glutamine synthetase (GS) and glutamate synthase (GOGAT) in flag leaf and grain were highest under MD, whereas glutamine acid-pyruvate (GPT) was highest at HD. Under SS, the tiller numbers, grain protein and grain yield were increased with the increasing planting density but without significant difference between MD and HD. Under NT, the tiller numbers and grain yield were highest with MD, whereas, the grain total protein, albumin, glutenin, gliadin, glutenin/gliadin were highest with LD. Our study demonstrated that subsoiling during fallow period with a planting density 260 plants $\mathrm{m}^{-2}$ was beneficial to achieve the simultaneous improvement of yield and grain protein content of dryland wheat in Loess Plateau.
\end{abstract}

Keywords: winter wheat, Loess Plateau, tillage, soil water storage, nitrogen metabolizing enzymes

\section{Introduction}

The yield of winter wheat (Triticum aestivum L.) in dryland area is unstable and substantially lower than the average yield in other areas of China and other European countries. Stabilizing the yield of dryland wheat and improving the overall production and grain quality of dryland areas have always been the main task of research for cultivation work in the arid regions of North China (Li, 2002; Ma et al., 2005).

Soil moisture is the main limiting factor for wheat production in dryland, which affects the nutrient transport in the plant, and determines the population structure, yield and quality of wheat (Xu et al., 2003; Xie et al., 2003). A large number of studies showed that subsoiling tillage practice has obviously enhanced the water storage and moisture retention in dryland cultivation (Bhatt and Khera, 2006; Williams et al., 2006; Zhang et al., 2004). Subsoiling during summer fallow period in Loess Plateau has increased the amount of soil precipitation and the soil water storage by $76 \mathrm{~mm}$ in 0-200 $\mathrm{cm}$ (Liao et al., 2002) which increased water use efficiency by $11 \%$ and wheat grain yield increased by $8 \%$ in Weibei dryland (Bai et al., 2014). In the hilly and sloping land 
of western Henan, the soil storage was increased by $23 \mathrm{~mm}$ in $0-160 \mathrm{~cm}$ soil layer before sowing after subsoiling treatment and the average yield was $703 \mathrm{~kg} \mathrm{ha}^{-1}$ higher than that of traditional farming, the yield increased by $19 \%$, and the water use efficiency increased by $17 \%$ (Wang et al., 2004). However, the effect of subsoiling on the quality of wheat varies with the amount of precipitation. After the subsoiling during fallow period in the dryland of the Loess Plateau, the protein content of the grain was reduced in the year with less precipitation $(335.0 \mathrm{~mm})$ and increased in years with normal precipitation $(534.7 \mathrm{~mm})$ and abundant precipitation $(673.1 \mathrm{~mm})$ (Sun et al., 2014).

It can be seen that different management strategies play an important role in determining the quality and yield of wheat. Numerous studies have documented how planting density (Zecevic et al., 2014) and different tillage treatments affect yield and yield components of wheat (Schillinger, 2005). Optimum planting density for winter wheat varies with the planting dates, planting conditions, and planting equipment (Lloveras et al., 2004; Zecevic et al., 2014). Tillering is found beneficial for winter wheat yield formation as part of yield compensation mechanism (Gaile et al., 2017). Planting density also affect tillering and higher population density has been showed associated with the early tiller cessation resulting in fewer tillers per plant (Sparkes et al., 2006). At higher population, most of red light is absorbed and far-red light is reflected. Therefore at higher density, the cessation of axillary bud growth is due to the reduction in light quality and intensity resulting in less number of tillers. On the other hand high red to far-red delayed tillering cessation with high tillers (Sparkes et al., 2006; Xie et al., 2016).

The seeding rate might cause different ecological structure of wheat population, affecting the soil moisture and nutrients, and thus affecting the growth and development of wheat. Under the low sowing level, wheat grain yield increases with the increase of seeding rate, but after a certain threshold value increasing the seeding rate might not increase and even lead to a decrease in grain yield (Bhatta et al., 2017; Zhang et al., 2016) and adjusting seeding rate can effectively regulate the formation of grain proteins. Li et al. (2010) showed that in the medium gluten wheat 'Lianmai 2' the grain protein content was increased with the increase of planting density in the range of $270-360 \times 10^{4}$ $\mathrm{ha}^{-1}$. Similarly, with the increase of planting density in the range of $240-285 \times 10^{4} \mathrm{ha}^{-1}$ the grain protein and component content and the ratio of grain glutenin to gliadin increased gradually in low gluten wheat variety 'Yangmai 12' (Liu et al., 2006). Ma et al. (2007) showed that the activity of the glutamine synthetase and glutamate synthase increased in the flag leaf at $15 \mathrm{~d}$ after anthesis and the protein content of the grain was increased with the increase of planting density in the $150-300 \times 10^{4} \mathrm{ha}^{-1}$ range in the high gluten wheat 'Yumai 49-198'. In order to simultaneously improve protein content and grain yield in wheat, protein yield is an important criteria, which is the product of grain yield and relative protein content and thus corresponds to the grain protein harvested per area. It showed a highly positive correlation with grain yield, but only a small correlation with protein content (Rapp et al., 2018).

It can be seen that the increasing seeding rate has a certain promoting effect on grain protein formation, but these results are mainly concentrated under the condition of full irrigation of the water, and the effect of seeding amount on soil moisture in dryland wheat field is less than that on the plant nitrogen absorption and grain protein formation. Therefore, this study attempts to explore the effect of subsoiling during fallow period on dryland wheat based on the analysis of soil moisture, grain yield, nitrogen metabolism enzyme activity, grain protein and component under different planting densities. This 
research tries to explore the suitable sowing quantity on synchronization increase of grain yield and protein content under the subsoiling water storage condition of dryland wheat during fallow period.

\section{Materials and Methods}

\section{Experimental site and meteorological condition}

Field experiment was conducted for two winter wheat growing seasons from 2012 to 2014 at the experimental station of Shanxi Agricultural University located in Wenxi county $\left(35^{\circ} 20^{\prime} \mathrm{N}, 111^{\circ} 17^{\prime} \mathrm{E}\right.$, and elevation $\left.639 \mathrm{~m}\right)$, Shanxi Province, China. Experimental site is typical hilly dryland area where precipitation is a sole source of moisture and most of the precipitation $(60-70 \%)$ is concentrated during the fallow period when field is left fallow. The average annual precipitation during experimental years and average from the last 12 years is presented in Fig. 1.

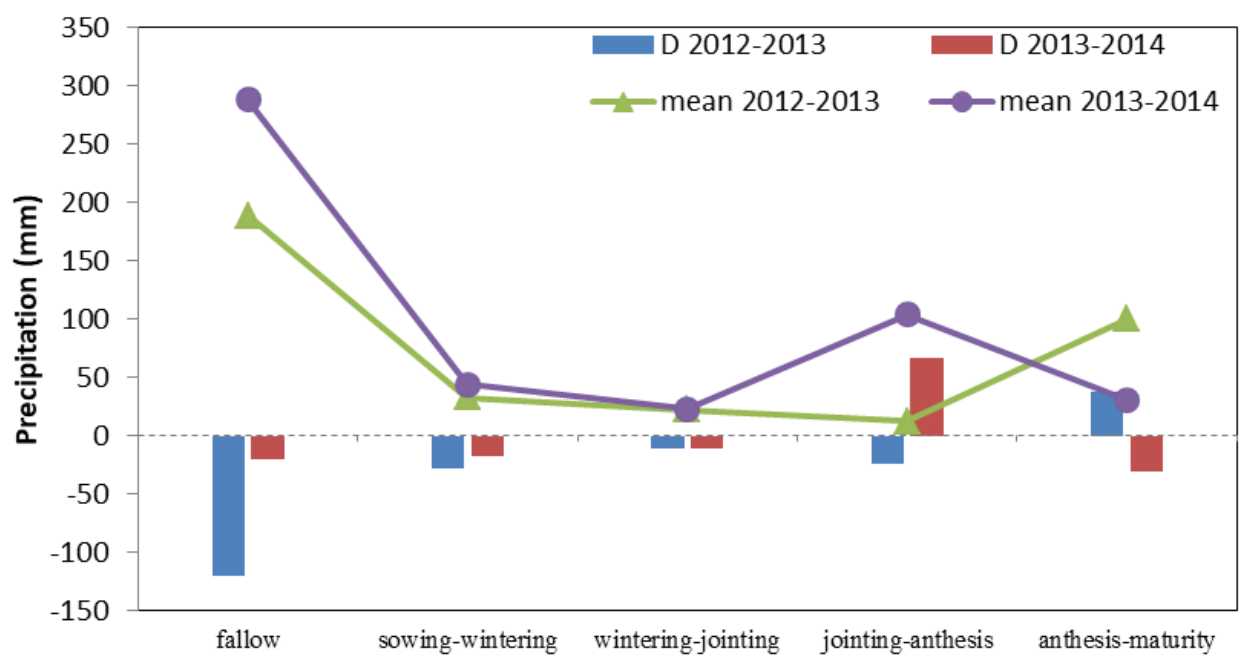

Figure 1. Precipitation during study years (2012-2014) and difference in precipitation in respective years from average precipitation in last 30 years (D 2012-2013 and D 2013-2014) in different growth stages of wheat at the experimental site in Wenxi

Precipitation was recorded during the fallow period (21 June - 30 September), sowing to wintering ( 1 October - 30 November), wintering to jointing (1 December to the following 10 April), jointing to flowering (11 April - 10 May), and from flowering to maturity (11 May - 20 June) stages. Average annual precipitation from 2002 to 2014 was $484 \mathrm{~mm}$, whereas total precipitation in 2012-2013 was $355.7 \mathrm{~mm}$, which is $26 \%$ lower than average precipitation, despite of higher precipitation from flowering to maturity. In 2013-2014 total precipitation was $489.7 \mathrm{~mm}$ which was closer to average annual precipitation. The basic nutrient properties of soil are shown in Table 1.

\section{Crop management}

After harvesting the previous wheat, $20-30 \mathrm{~cm}$ wheat stubble was left in field until mid-July. Subsoiling was performed during fallow period by subsoiler (IS-200, Xiuyuan Agricultural Machinery Co.) at the depth of $30-40 \mathrm{~cm}$ on 15 th July in the two years, 
followed by rotary tillage to crumble large soil lumps and to level the field on 25 August, 2012 and 23 August, 2013. The seeds of winter wheat variety 'Yunhan20410' provided by the Agricultural Bureau of Wenxi, Shanxi province were sown on 1 October 2012 and 29 September 2013. Before sowing, nitrogen (N, $\left.150 \mathrm{~kg} \mathrm{ha}^{-1}\right)$, phosphorus $\left(\mathrm{P}_{2} \mathrm{O}_{5}, 150 \mathrm{~kg} \mathrm{ha}^{-1}\right)$, and potassium $\left(\mathrm{K}_{2} \mathrm{O}, \mathrm{kg} \mathrm{ha}^{-1}\right)$ were applied to soil and no top dressing was applied during the rest of growth period. No irrigation was applied during the experiment. Wheat was harvested on 20 June.

Table 1. Soil nutrient properties from experimental location in Shanxi (6 June 2012 and 2013)

\begin{tabular}{c|c|c}
\hline Soil nutrients & $\mathbf{2 0 1 2}$ & $\mathbf{2 0 1 3}$ \\
\hline Organic matter $\left(\mathrm{g} \mathrm{kg}^{-1}\right)$ & 11.88 & 10.88 \\
Total nitrogen $\left(\mathrm{g} \mathrm{kg}^{-1}\right)$ & 0.61 & 0.85 \\
Alkali-hydrolysis nitrogen $\left(\mathrm{mg} \mathrm{kg}^{-1}\right)$ & 38.62 & 39.32 \\
Available phosphorous $\left(\mathrm{mg} \mathrm{kg}^{-1}\right)$ & 14.61 & 16.62 \\
Available potassium $\left(\mathrm{mg} \mathrm{kg}^{-1}\right)$ & 238.16 & 221.56 \\
$\mathrm{pH}$ & 8.08 & 8.12 \\
\hline
\end{tabular}

\section{Experimental design}

The experiment was conducted with two-factor split plot design, taking the tillage practice as a main factor, and planting density as a sub-plot factor. Two tillage practices were the subsoiling (SS) and no tillage (NT). Under each tillage method, three planting

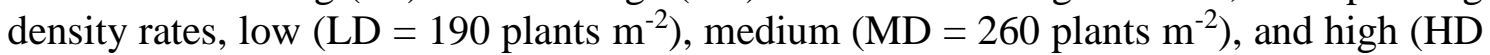
$=320$ plants $\mathrm{m}^{-2}$ ) were used in the experiment. Seeds were sown at the rate of $67.5,90$ and $112.5 \mathrm{~kg} \mathrm{ha}^{-1}$ after which at 3-leaf stage planting density of 190, 260 and 320 plants $\mathrm{m}^{-2}$ were attained by thinning. Each treatment was repeated 3 times with a total of 18 plots. Each sub-plot $\left(150 \mathrm{~m}^{2}\right)$ was $50 \mathrm{~m}$ long and $3 \mathrm{~m}$ wide and a line spacing of $30 \mathrm{~cm}$.

\section{Measurements}

\section{Soil water storage}

Soil samples were taken before sowing and at anthesis stage after every $20 \mathrm{~cm}$ from 0 to $300 \mathrm{~cm}$ depth from each subplot with 3 replicates for each treatment. Soil samples were weighed wet, dried in oven at $105^{\circ} \mathrm{C}$ for $48 \mathrm{~h}$, and weighed again to determine the soil water content. From each plot, gravimetric water content at a given layer was determined by averaging the values from three random sampling points placed between two plants in the row. Before the setup of plots the soil bulk density $\left(\mathrm{g} \mathrm{cm}^{-3}\right)$ was measured at $20 \mathrm{~cm}$ increments to a depth of $300 \mathrm{~cm}$ from the whole soil profile (0-300 cm depth).

$$
\text { Soil water content }(\%)=\frac{\text { wet weight-dry weight }}{\text { dry weight }} \times 100
$$

Soil water storage was determined from soil water content by using following formula:

$$
\operatorname{SWSi}(\mathrm{mm})=W i \times D i \times H i \times 10 / 100
$$


where $\mathrm{SWS}_{\mathrm{i}}$ : soil moisture of layer i $(\mathrm{mm}) ; \mathrm{W}_{\mathrm{i}}$ : soil water content of layer i $(\%) ; \mathrm{D}_{\mathrm{i}}$ : soil bulk density of layer i $\left(\mathrm{g} \mathrm{cm}^{-3}\right) ; \mathrm{H}_{\mathrm{i}}$ : thickness of layer $\mathrm{i}(\mathrm{cm})$.

\section{Protein and protein fractions in grains}

At flowering, the fifteen ears with uniform flowering time and size were picked. Grains were separated in the oven where moisture was removed by heating at $105^{\circ} \mathrm{C}$ for $30 \mathrm{~min}$ and then weighted after drying at $80^{\circ} \mathrm{C}$. Grains were used to measure the protein contents and protein fractions after being crushed by micro high-speed universal grinder (DE-100 g). Content of albumin, globulin, gliadin, and glutelin in grains were measured using the method of continuous extraction. Nitrogen content was determined using semi micro Kjeldahl method and wheat protein content was obtained by multiplying $\mathrm{N}$ content (\%) by 5.7 (Halvorson et al., 2004). The protein yield was obtained in $\mathrm{tha}^{-1}$ as

$$
\text { protein yield }=\text { grain yield } \times \text { protein content } / 100
$$

\section{Enzyme activity related to nitrogen metabolism}

Plants at same growth and flowering time were labelled during anthesis. Fifteen labeled ears and flag leaves were taken at 5, 10, 15, 20, 25, and $30 \mathrm{~d}$ of anthesis and quickly frozen in liquid nitrogen and stored at $-40^{\circ} \mathrm{C}$. The activity of glutamine synthetase (GS) and glutamate synthase (GOGAT) was determined by the method described by Lin et al. (1996) and Lu et al. (2005) and glutamate pyruvate transaminase (GPT) was determined by the method described by Wu and Tao (2003).

\section{Population tiller numbers and grain yield}

At 3-leaf stage the plants from $1 \mathrm{~m}^{2}$ were selected from each plot and number of tiller population was investigated by counting tillers at wintering, jointing, booting, anthesis and maturity stages. At maturity, plants from $1 \mathrm{~m}^{2}$ were harvested from each plot to determine the grain yield $\left(\mathrm{kg} \mathrm{ha}^{-1}\right)$.

\section{Statistical analysis}

Data were subjected to analysis of variance (ANOVA) as split-plot design using DPS and SAS 9.0. Graphs were constructed using Microsoft Excel 2007. Mean values were calculated and significance of the difference between treatments was tested by LSD (least significant difference) method at the significance level of $P=0.05$.

\section{Results}

\section{Effects of subsoiling during fallow period on soil moisture content at sowing and anthesis stage}

With the increase of soil depth, the soil water content at sowing time varied with the depth and was highest in 0-60 cm which then decreased from 60-200 cm and then again increased in 200-300 cm (Fig. 2). The subsoiling (SS) during fallow period has proved effective for increasing the soil moisture content at sowing time as compared to no tillage (NT) especially in 0-160 cm and in 200-240 cm soil depth during 2012-2013, and 0-200 cm and 260-300 cm in 2013-2014. At flowering stage the trend of soil moisture content varies in both years. The difference in moisture content under SS and NT was 
more significant during 2012-2013 when the soil moisture in 40-300 $\mathrm{cm}$ soil layer was higher in SS. In 2013-2014 the difference of soil moisture content was less prominent between SS and NT with higher soil moisture in 40-60 cm and 200-300 cm. It can be seen that SS during fallow period is conducive for the accumulation of precipitation in soil during fallow period especially during the year with less precipitation (2012-2013) and the effect of moisture storage may continue up to the flowering.
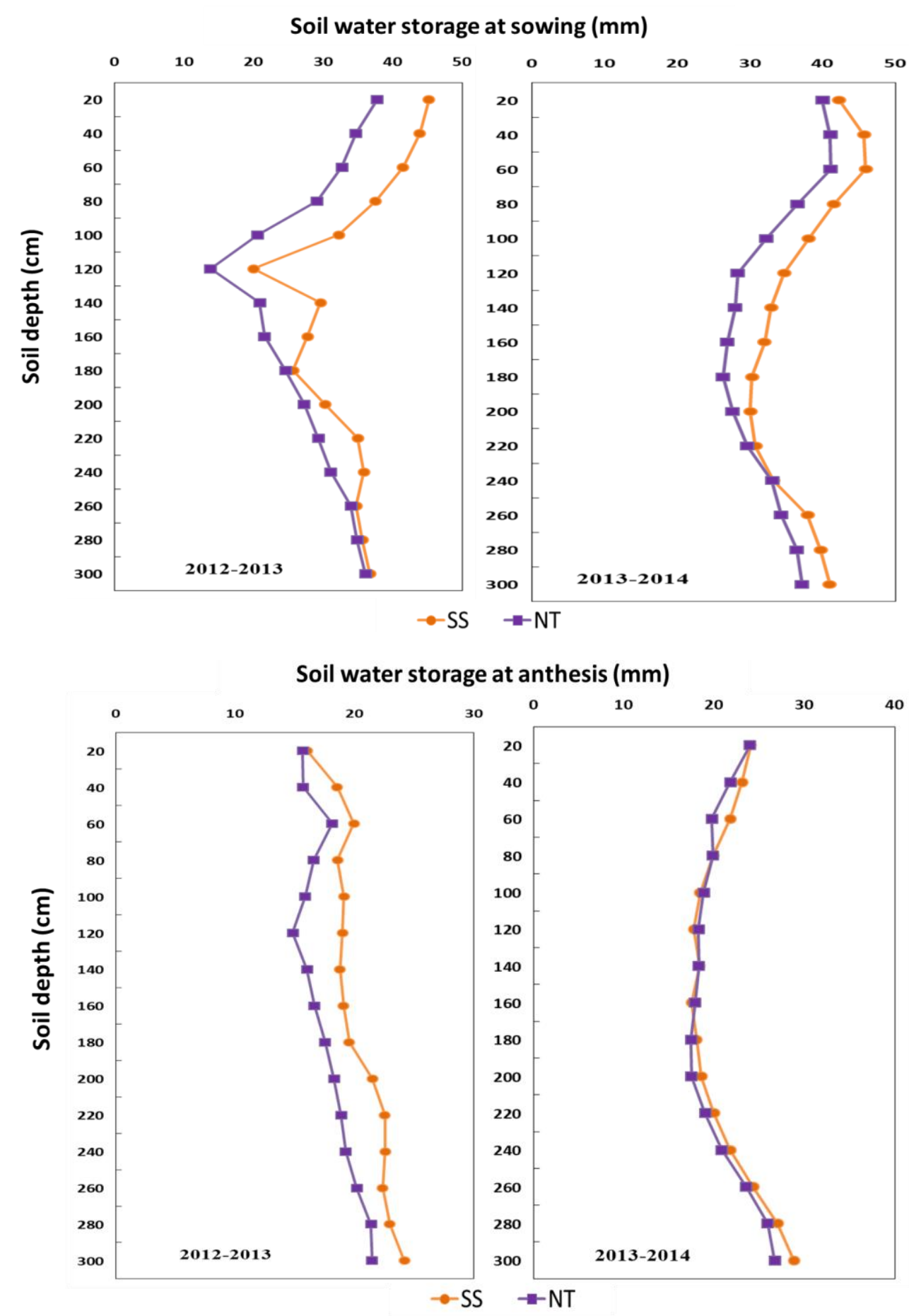

Figure 2. Effect of subsoiling during fallow period on soil water storage at sowing and anthesis of dryland wheat (SS: subsoiling; NT: no tillage) 


\section{Effect of planting density on soil moisture storage at anthesis stage under subsoiling}

Under subsoiling during fallow period, the soil water content was highest in LD and lowest in MD (Fig. 3). At lowest planting density, soil moisture in 40-200 cm and 260$300 \mathrm{~cm}$ soil during 2012-2013 and 0-300 cm soil depth in 2013-2014 was higher than MD and HD. In 2012-2013, soil moisture in 80-200 cm soil, and in 2013-2014, soil moisture in 20-260 cm soil was higher in HD than MD. It can be seen that the planting density rate has certain regulatory effect on the soil moisture during flowering period, especially in 2013-2014.

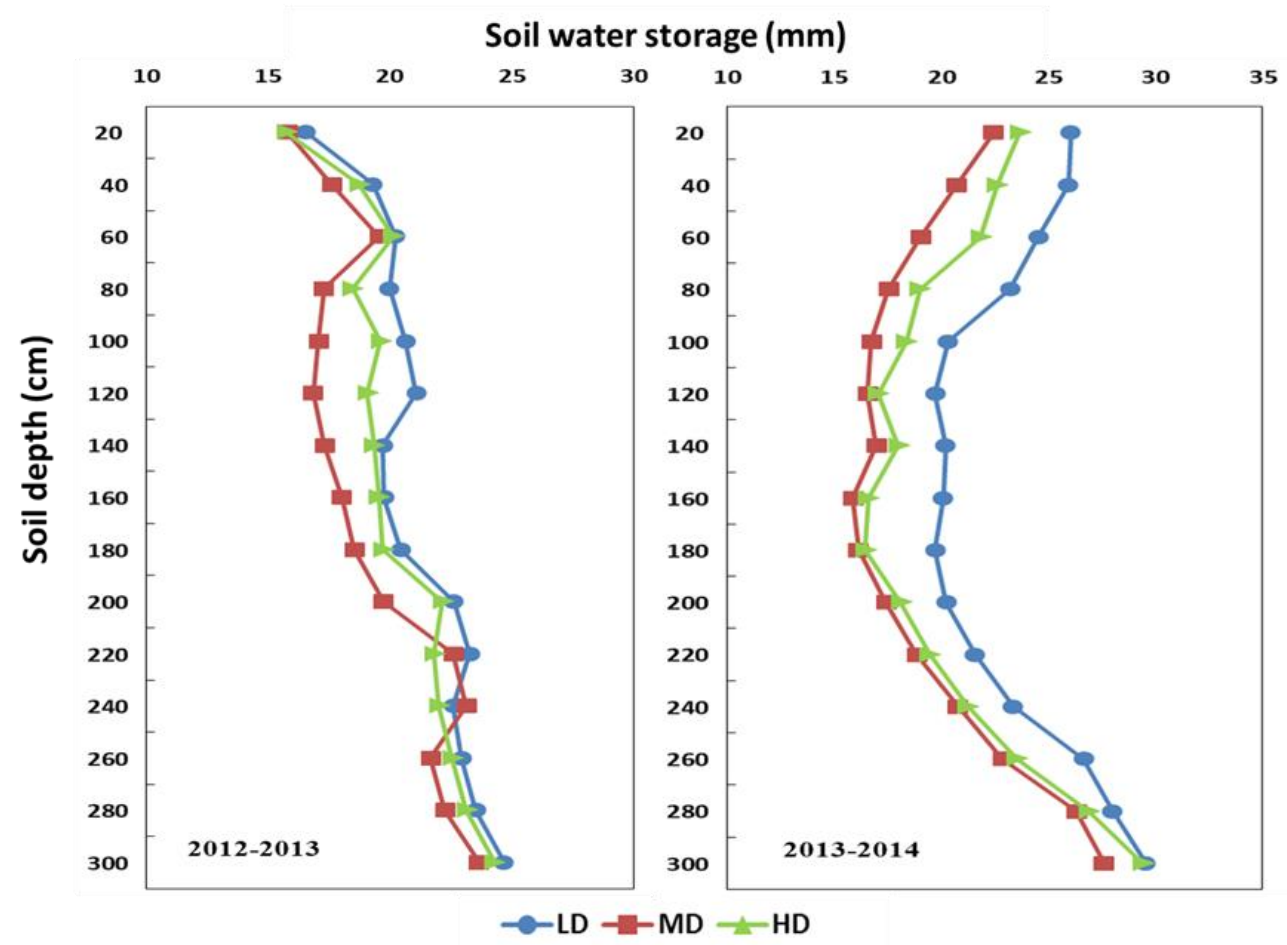

Figure 3. Effect of different planting density under subsoiling condition on soil water storage at anthesis of dryland wheat (LD: 190 plants $\mathrm{m}^{-2} ; M D: 260$ plants $\mathrm{m}^{-2}$; HD: 320 plants $\mathrm{m}^{-2}$ )

\section{Effects of subsoiling and planting density on the number of group tillers}

The numbers of tillers were significantly higher after SS conducted during fallow period than that in NT (Table 2). Under SS, the increasing planting density had significantly increased the tillers and the difference between three planting density was significant during wintering period. From jointing to maturity stage, increasing planting density rate from LD to MD has significantly increased the tillers whereas the difference between the MD and HD was not significant. Under NT condition, the number of tillers was highest at the medium density, and the difference between LD and MD was significant during wintering and booting stage and difference between MD and HD was significant from wintering to booting stage. Lowest tillers from jointing to mature stages were recorded at HD, while in wintering stage the lowest tillers were found at LD. It can be seen that SS during fallow period is beneficial for the formation of more tillers at high planting density which is advantageous for the formation of 
effective spike number, but the difference between medium and high sowing rate was not significant.

Table 2. Effect of subsoiling during fallow period and seeding rates on tillers group $\left(\times 10^{4}\right.$ $\left.h^{-1}\right)$ at different growth stages in 2013-2014

\begin{tabular}{|c|c|c|c|c|c|c|}
\hline \multicolumn{2}{|c|}{ Treatment } & \multirow[b]{2}{*}{ Wintering } & \multirow[b]{2}{*}{ Jointing } & \multirow[b]{2}{*}{ Booting } & \multirow[b]{2}{*}{ Anthesis } & \multirow[b]{2}{*}{ Maturity } \\
\hline Tillage & $\begin{array}{l}\text { Seeding } \\
\text { rate }\end{array}$ & & & & & \\
\hline \multirow{3}{*}{ SS } & $\mathrm{LD}$ & $1005.00 \pm 16.42 \mathrm{~d}$ & $1142.15 \pm 26.97 b$ & $580.15 \pm 16.17 b$ & $501.24 \pm 10.99 \mathrm{~b}$ & $479.00 \pm 7.00 \mathrm{~b}$ \\
\hline & MD & $1204.23 \pm 17.59 b$ & $1348.50 \pm 30.06 \mathrm{a}$ & $690.00 \pm 20.23 \mathrm{a}$ & $540.00 \pm 10.69 \mathrm{a}$ & $501.75 \pm 9.75 \mathrm{a}$ \\
\hline & HD & $1328.25 \pm 17.95 \mathrm{a}$ & $1398.52 \pm 36.74 \mathrm{a}$ & $710.25 \pm 15.21 \mathrm{a}$ & $561.23 \pm 12.11 \mathrm{a}$ & $510.25 \pm 3.25 \mathrm{a}$ \\
\hline \multirow{3}{*}{ NT } & $\mathrm{LD}$ & $963.50 \pm 10.45 \mathrm{e}$ & $1032.15 \pm 20.02 \mathrm{~cd}$ & $520.14 \pm 16.14 \mathrm{c}$ & $465.65 \pm 11.30 \mathrm{c}$ & $446.75 \pm 7.25 \mathrm{c}$ \\
\hline & MD & $1064.75 \pm 15.90 \mathrm{c}$ & $1106.00 \pm 23.26 \mathrm{bc}$ & $575.58 \pm 13.61 b$ & $486.23 \pm 13.28 b c$ & $458.50 \pm 3.00 \mathrm{bc}$ \\
\hline & HD & $985.50 \pm 8.00 \mathrm{de}$ & $1000.32 \pm 28.13 d$ & $501.23 \pm 117.24 \mathrm{c}$ & $456.25 \pm 11.00 \mathrm{c}$ & $438.25 \pm 1.75 \mathrm{c}$ \\
\hline \multicolumn{2}{|c|}{ ANOVA } & & & & & \\
\hline \multicolumn{2}{|c|}{$\begin{array}{c}\text { Tillage }\left(F_{T}\right) \\
\text { Seeding rate }\left(F_{S}\right)\end{array}$} & $\begin{array}{l}330.56 \\
181.45^{\text {*** }}\end{array}$ & $\begin{array}{l}128.85^{*} \\
78.99^{* *}\end{array}$ & $\begin{array}{l}159.60^{*} \\
19.02^{* *}\end{array}$ & $\begin{array}{l}33.21^{*} \\
8.84^{* *}\end{array}$ & $\begin{array}{c}1295.86^{*} \\
5.14^{*}\end{array}$ \\
\hline \multicolumn{2}{|c|}{$F_{T} \times F_{S}$} & $121.54^{* *}$ & $74.70^{* *}$ & $15.23^{* *}$ & $11.15^{* *}$ & $7.03^{*}$ \\
\hline
\end{tabular}

SS: subsoiling; NT: no tillage; LD, MD and HD are planting density of 190, 260 and 320 plants $\mathrm{m}^{-2}$. *, ${ }^{* *}$ and ${ }^{* * *}$ indicate significance at $\mathrm{p}<0.05, \mathrm{p}<0.01$ and $\mathrm{p}<0.001$, respectively

\section{Effects of subsoiling and planting density on protein fractions of wheat grain in dryland}

Wheat grain yield, grain protein and protein components were significantly influenced by the years, tillage treatment and planting density (Table 3). Average grain yield in 2012-2013 was $3044 \mathrm{~kg} \mathrm{ha}^{-1}$ which was lower than in the year 2013-2014 with grain yield of $4705 \mathrm{~kg} \mathrm{ha}^{-1}$, therefore less grain yield was produced in years with less precipitation as compared to years which received high precipitation. The grain protein and protein fractions were significantly higher in year with less precipitation (20122013) than with more precipitation (2013-2014). The SS during fallow period had significantly increased the grain yield compared with the NT, and increase in grain yield under SS was $26 \%-66 \%$ in 2012-2013 and 17\%-34\% in 2013-2014 as compared to NT. Under SS, increasing planting density has increased the grain yield but the difference between the MD and the HD was not significant, whereas in NT, maximum yield was the achieved at MD and increasing planting density to HD has decreased grain yield.

The grain albumin, gliadin, glutenin, glutenin/gliadin ratio and total protein content were decreased by SS, in contrast to which globulin content and protein yield was increased under SS as compared with NT. Protein yield was increased significantly with SS as compared with NT. Under SS and NT the protein yield was increased by increasing planting density from LD to MD which then decreased by further increasing HD during both years.

Under SS, albumin, globulin, gliadin and glutenin were highest at MD and decreased under the condition of low and high sowing rates during both years. Under no tillage condition (NT), albumin, gliadin, glutenin, total protein content, and glutenin/gliadin ratio were highest in low sowing rate (LD) and lowest in high sowing rate (HD). It can be seen that the precipitation is favourable to increase yield of dryland wheat, but unfavourable for protein accumulation in grain. 
Table 3. Effect of subsoiling during fallow period and seeding rates on protein and protein fractions of wheat grain

\begin{tabular}{|c|c|c|c|c|c|c|c|c|c|c|}
\hline \multicolumn{3}{|c|}{ Treatment } & \multirow{2}{*}{$\begin{array}{l}\text { Albumin } \\
(\%)\end{array}$} & \multirow{2}{*}{$\begin{array}{l}\text { Globulin } \\
\text { (\%) }\end{array}$} & \multirow{2}{*}{$\begin{array}{l}\text { Gliadin } \\
(\%)\end{array}$} & \multirow{2}{*}{$\begin{array}{l}\text { Glutenin } \\
(\%)\end{array}$} & \multirow[b]{2}{*}{ Glu/Gli } & \multirow{2}{*}{$\begin{array}{c}\text { Protein content } \\
\qquad(\%)\end{array}$} & \multirow{2}{*}{$\begin{array}{l}\text { Protein yield } \\
\quad\left(\mathrm{kg} \mathrm{ha}^{-1}\right)\end{array}$} & \multirow{2}{*}{$\begin{array}{l}\text { Grain yield } \\
\left(\mathrm{kg} \mathrm{ha}^{-1}\right)\end{array}$} \\
\hline Years & Tillage & $\begin{array}{c}\text { Seeding } \\
\text { rate }\end{array}$ & & & & & & & & \\
\hline \multirow[t]{6}{*}{$2012-2013$} & \multirow{3}{*}{ SS } & LD & $2.87 \mathrm{c}$ & $1.80 \mathrm{~cd}$ & $4.42 \mathrm{c}$ & $4.77 \mathrm{c}$ & $1.08 \mathrm{c}$ & $14.96 \mathrm{c}$ & $476.5 \mathrm{c}$ & $3185.6 \mathrm{~b}$ \\
\hline & & MD & $2.97 \mathrm{~b}$ & $1.85 \mathrm{a}$ & $4.54 \mathrm{ab}$ & $5.20 \mathrm{~b}$ & $1.15 \mathrm{ab}$ & $15.46 \mathrm{~b}$ & $586.8 \mathrm{a}$ & $3795.1 \mathrm{a}$ \\
\hline & & $\mathrm{HD}$ & $2.93 \mathrm{bc}$ & $1.82 \mathrm{bc}$ & $4.46 \mathrm{bc}$ & $4.87 \mathrm{c}$ & $1.09 \mathrm{c}$ & $15.09 \mathrm{c}$ & $576.3 \mathrm{~b}$ & $3819.5 \mathrm{a}$ \\
\hline & \multirow{3}{*}{ NT } & LD & $3.12 \mathrm{a}$ & $1.78 \mathrm{~d}$ & $4.65 \mathrm{a}$ & $5.43 \mathrm{a}$ & $1.18 \mathrm{a}$ & $16.09 \mathrm{a}$ & $408.2 \mathrm{~d}$ & $2537.5 \mathrm{~d}$ \\
\hline & & MD & $2.99 \mathrm{~b}$ & $1.83 \mathrm{ab}$ & $4.56 \mathrm{a}$ & $5.22 \mathrm{~b}$ & $1.14 \mathrm{ab}$ & $15.61 \mathrm{~b}$ & $409.5 \mathrm{~d}$ & $2621.7 \mathrm{c}$ \\
\hline & & HD & $2.95 \mathrm{~b}$ & $1.78 \mathrm{~d}$ & $4.53 \mathrm{ab}$ & $5.12 \mathrm{~b}$ & $1.13 \mathrm{~b}$ & $15.47 \mathrm{~b}$ & $356.5 \mathrm{e}$ & $2304.1 \mathrm{e}$ \\
\hline \multirow[t]{6}{*}{ 2013-2014 } & \multirow{3}{*}{$\mathrm{SS}$} & LD & $2.40 \mathrm{c}$ & $1.46 \mathrm{~b}$ & $4.09 \mathrm{c}$ & $4.06 \mathrm{c}$ & $0.99 \mathrm{~b}$ & $12.99 \mathrm{~d}$ & $635.5 \mathrm{~b}$ & $4892.9 \mathrm{~b}$ \\
\hline & & MD & $2.68 \mathrm{~b}$ & $1.49 \mathrm{a}$ & $4.27 \mathrm{ab}$ & $4.46 \mathrm{~b}$ & $1.04 \mathrm{a}$ & $13.75 \mathrm{~b}$ & $728.0 \mathrm{a}$ & $5292.8 \mathrm{a}$ \\
\hline & & HD & $2.49 \mathrm{c}$ & $1.47 \mathrm{~b}$ & $4.15 b c$ & $4.17 \mathrm{c}$ & $1.01 \mathrm{~b}$ & $13.39 \mathrm{c}$ & $718.0 \mathrm{a}$ & $5360.7 \mathrm{a}$ \\
\hline & \multirow{3}{*}{ NT } & LD & $2.87 \mathrm{a}$ & $1.42 \mathrm{~d}$ & $4.35 \mathrm{a}$ & $4.64 \mathrm{a}$ & $1.07 \mathrm{a}$ & $14.33 \mathrm{a}$ & $597.1 \mathrm{c}$ & $4167.6 \mathrm{~d}$ \\
\hline & & MD & $2.73 \mathrm{~b}$ & $1.44 \mathrm{c}$ & $4.29 \mathrm{a}$ & $4.49 \mathrm{~b}$ & $1.05 \mathrm{a}$ & $13.87 \mathrm{~b}$ & $626.5 \mathrm{~b}$ & $4515.9 \mathrm{c}$ \\
\hline & & HD & $2.64 \mathrm{~b}$ & $1.41 \mathrm{~d}$ & $4.27 \mathrm{ab}$ & $4.37 \mathrm{~b}$ & $1.02 \mathrm{~b}$ & $13.85 \mathrm{~b}$ & $554.0 \mathrm{~d}$ & $4001.7 \mathrm{~d}$ \\
\hline \multirow[t]{4}{*}{ ANOVA } & \multicolumn{2}{|c|}{ Years (Fy) } & $10404.0^{* *}$ & $17089.0^{* *}$ & $28561.0^{* *}$ & $21707.1^{* *}$ & $3481.0^{* *}$ & $3230.5^{*}$ & $6198.6^{* *}$ & $102828.0^{* * *}$ \\
\hline & \multicolumn{2}{|c|}{ Tillage (FT) } & $1881.8^{* *}$ & $40.7^{*}$ & $217.8^{* *}$ & $3741.1^{* *}$ & $230.4^{* *}$ & $562.1^{* *}$ & $79201.8^{* *}$ & $822.9^{* *}$ \\
\hline & \multicolumn{2}{|c|}{ Seeding rate (FS) } & $50.82^{* *}$ & $5.38^{*}$ & $76.70^{* *}$ & $559.68^{* *}$ & $147.2^{* *}$ & $7.76^{*}$ & $501.8^{* *}$ & $47.27^{* *}$ \\
\hline & \multicolumn{2}{|c|}{$\mathrm{Fy} \times \mathrm{FT} \times \mathrm{FS}$} & $15.60^{* *}$ & 0.03 & $6.48^{*}$ & $8.32^{*}$ & $10.75^{* *}$ & 0.53 & $19.20^{* *}$ & $5.10^{*}$ \\
\hline
\end{tabular}

Values followed by different letters are significantly different at $\mathrm{P}<0.05$, SS: subsoiling; NT: no tillage; LD, MD and HD are planting density of 190,260 and 320 plants $\mathrm{m}^{-2} .{ }^{*},{ }^{* *}$ and ${ }^{* * *}$ indicate significance at $\mathrm{p}<0.05, \mathrm{p}<0.01$ and $\mathrm{p}<0.001$, respectively 
Subsoiling proved beneficial to increase the grain yield and protein yield, but the difference between the medium and the high planting density was not significant, while the SS in the fallow period decreased the content of total protein, albumin, gliadin and glutenin, but the decrease was not significant at the medium sowing rate. Therefore, the medium planting density was more favourable under SS.

\section{Effects of planting density on activity of nitrogen metabolizing enzymes in flag leaves and grains}

Nitrogen metabolizing enzymes were tested under subsoiling during fallow field at different planting density at 5 days interval after anthesis. GS and GOGAT activities in flag leaf were highest in medium planting density (MD) followed by highest planting density (HD) and minimum activities were found in lowest planting density (LD) (Fig. 4). The activities of GS and GOGAT reduced with time after anthesis. Therefore, under subsoiling during fallow period, the medium density was advantageous for increasing the activities of GS and GOGAT in flag leaves.
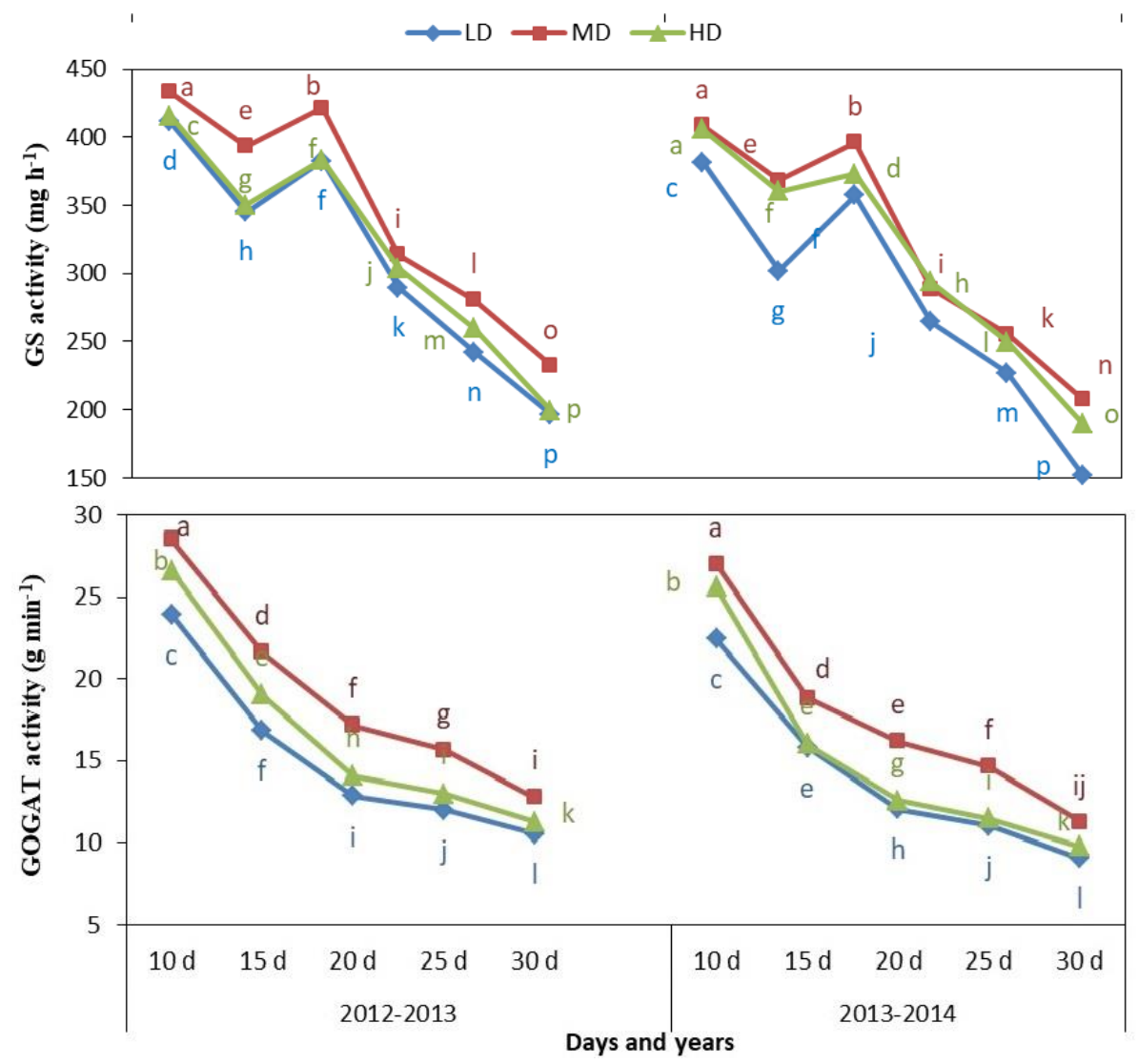

Figure 4. Effect of different planting density under subsoiling condition on activity of glutamine synthetase (GS) and glutamate synthase (GOGAT) in flag leaves after anthsis of dryland wheat (LD: 190 plants $\mathrm{m}^{-2}$; MD: 260 plants $\mathrm{m}^{-2} ; H D: 320$ plants $\mathrm{m}^{-2}$ )

In grains GS activity was highest at MD and lowest in LD (Fig. 5). GOGAT activity was also highest in MD except $20 \mathrm{~d}$ after anthesis during $2013^{-2} 014$ and $30 \mathrm{~d}$ after anthesis during both years. The GPT activity was highest at HD during 10, 15, 25 and $30 \mathrm{~d}$ after anthesis with only exception of $20 \mathrm{~d}$ after anthesis during both years, whereas 
lowest GPT activity was recorded at LD (Fig. 5). It can be seen that the medium and high planting density were more favourable to improve the GS, GOGAT and GPT activities in grain; especially the medium density has a greater effect on the grain GS and the GOGAT activities during early stages of grain filling.

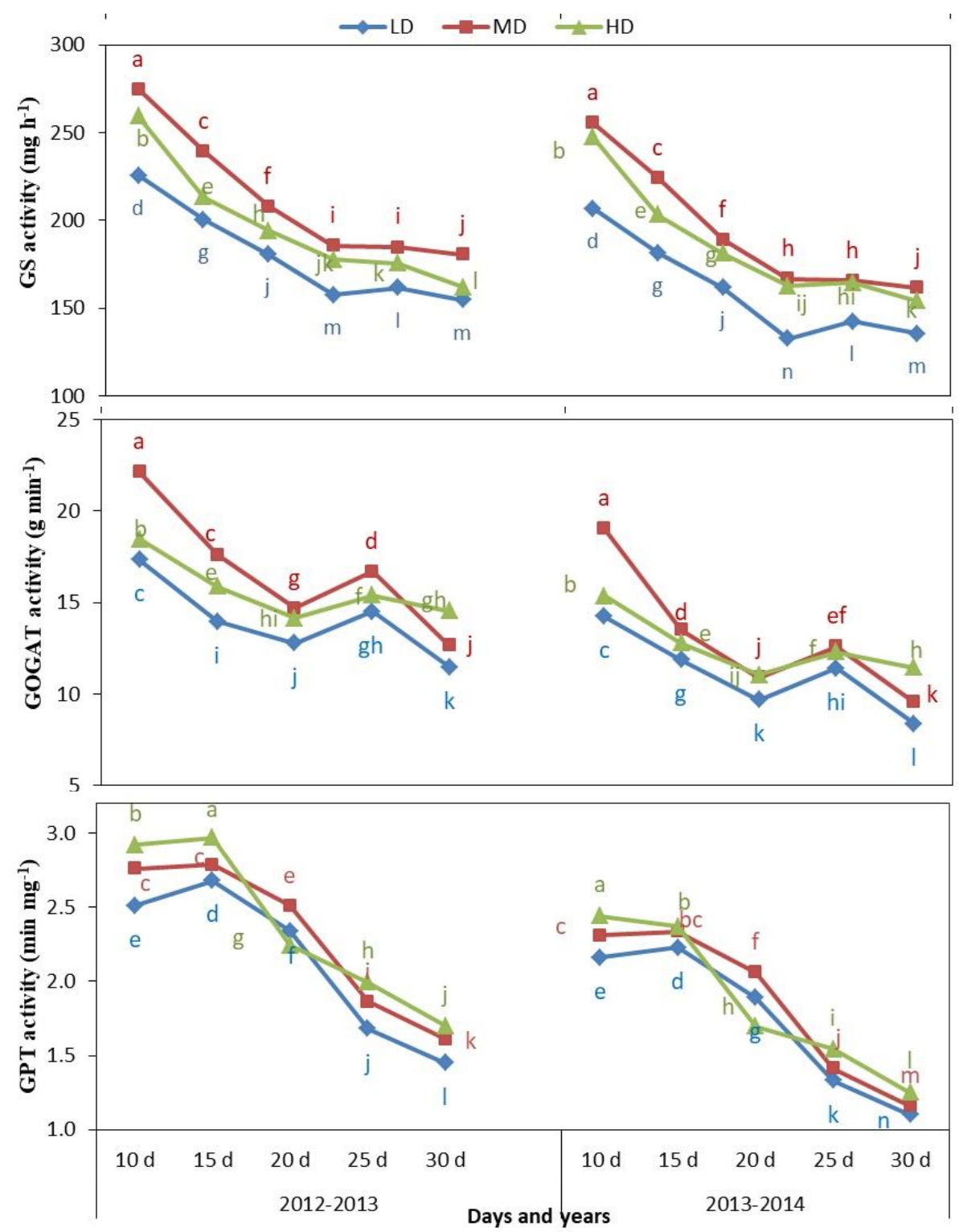

Figure 5. Effect of different planting density under subsoiling condition on activity of glutamine synthetase (GS), glutamate synthase (GOGAT) and glutamate pyruvate transaminase (GPT) in grains after anthesis of dryland wheat (LD: 190 plants $\mathrm{m}^{-2}$; MD: 260 plants $\mathrm{m}^{-2}$; HD: 320 plants $\mathrm{m}^{-2}$ )

\section{Relationship between soil moisture and grain protein at anthesis, and soil moisture content and protein yield and grain yield}

Correlation coefficients indicated that albumin, globulin, gliadin and protein content were negatively related with the soil moisture content at anthesis (Table 4). In 20122013 , albumin content was significantly related with moisture in $120-220 \mathrm{~cm}$, while 
gliadin, glutenin and protein contents showed negative significant relationship with soil moisture in $120-200 \mathrm{~cm}$ and then $260-300 \mathrm{~cm}$ soil layer. Protein yield showed significant correlation with soil moisture at 240 and $300 \mathrm{~cm}$ soil layer. In 2013-2014, during which the precipitation was more, the soil moisture in upper and lowest layer showed significant negative relationship with protein contents. Albumin, gliadin, glutenin and protein contents were negatively affected with soil moisture in $20-100 \mathrm{~cm}$ and $300 \mathrm{~cm}$ soil layer.

Table 4. Correlation coefficient between soil water storage at anthesis and grain protein accumulation

\begin{tabular}{|c|c|c|c|c|c|c|c|c|}
\hline Years & $\begin{array}{l}\text { Soil depth } \\
\text { (cm) }\end{array}$ & Albumin & Globulin & Gliadin & Glutenin & Glu/Gli & Protein content & Protein yield \\
\hline \multirow{15}{*}{$\begin{array}{l}2012- \\
2013\end{array}$} & 20 & 0.594 & -0.179 & 0.274 & 0.351 & 0.372 & 0.459 & 0.059 \\
\hline & 40 & -0.136 & 0.149 & -0.465 & -0.382 & -0.353 & -0.320 & 0.633 \\
\hline & 60 & 0.104 & 0.072 & -0.255 & -0.170 & -0.142 & -0.091 & 0.538 \\
\hline & 80 & -0.237 & 0.122 & -0.483 & -0.448 & -0.439 & -0.355 & 0.276 \\
\hline & 100 & -0.453 & -0.049 & $-0.770^{*}$ & -0.717 & -0.699 & -0.616 & 0.463 \\
\hline & 120 & $-0.822^{*}$ & 0.288 & $-0.939^{* *}$ & $-0.914^{* *}$ & $-0.901^{* *}$ & $-0.904^{* *}$ & 0.580 \\
\hline & 140 & $-0.831^{*}$ & 0.421 & $-0.905^{* *}$ & $-0.903^{* *}$ & $-0.899^{* *}$ & $-0.912^{* *}$ & 0.614 \\
\hline & 160 & $-0.871^{*}$ & 0.388 & $-0.942^{* *}$ & $-0.932^{* *}$ & $-0.924^{* *}$ & $-0.951^{* *}$ & 0.657 \\
\hline & 180 & $-0.914^{* *}$ & 0.469 & $-0.862^{*}$ & $-0.885^{* *}$ & $-0.889^{* *}$ & $-0.926^{* *}$ & 0.473 \\
\hline & 200 & $-0.924^{* *}$ & 0.394 & $-0.928^{* *}$ & $-0.943^{* *}$ & $-0.943^{* *}$ & $-0.968^{* *}$ & 0.532 \\
\hline & 220 & $-0.784^{*}$ & 0.668 & -0.748 & -0.721 & -0.705 & $-0.812^{*}$ & 0.745 \\
\hline & 240 & -0.650 & 0.646 & -0.662 & -0.607 & -0.580 & -0.709 & $0.888^{* *}$ \\
\hline & 260 & -0.750 & 0.465 & $-0.862^{*}$ & $-0.832^{*}$ & $-0.817^{*}$ & $-0.852^{*}$ & 0.742 \\
\hline & 280 & -0.652 & 0.289 & $-0.854^{*}$ & $-0.808^{*}$ & $-0.789^{*}$ & $-0.786^{*}$ & 0.693 \\
\hline & 300 & -0.661 & 0.243 & $-0.828^{*}$ & $-0.765^{*}$ & -0.737 & $-0.778^{*}$ & $0.760^{*}$ \\
\hline \multirow{15}{*}{$\begin{array}{c}2013- \\
2014\end{array}$} & 20 & $-0.935^{* *}$ & 0.675 & $-0.933^{\text {** }}$ & $-0.911^{\text {** }}$ & $-0.878^{\text {*** }}$ & $-0.944^{* *}$ & 0.524 \\
\hline & 40 & $-0.904^{* *}$ & 0.689 & $-0.925^{* *}$ & $-0.882^{* *}$ & $-0.835^{*}$ & $-0.966^{* *}$ & 0.530 \\
\hline & 60 & $-0.919^{* *}$ & 0.642 & $-0.912^{* *}$ & $-0.895^{* *}$ & $-0.865^{*}$ & $-0.964^{* *}$ & 0.493 \\
\hline & 80 & $-0.861^{*}$ & 0.558 & $-0.880^{* *}$ & $-0.843^{*}$ & $-0.801^{*}$ & $-0.939^{* *}$ & 0.372 \\
\hline & 100 & $-0.763^{*}$ & 0.668 & $-0.790^{*}$ & -0.741 & -0.689 & $-0.857^{*}$ & 0.538 \\
\hline & 120 & 0.033 & -0.414 & -0.077 & -0.021 & 0.009 & -0.006 & -0.499 \\
\hline & 140 & -0.147 & -0.226 & -0.273 & -0.203 & -0.159 & 0.159 & -0.295 \\
\hline & 160 & -0.173 & -0.389 & -0.261 & -0.223 & -0.202 & -0.215 & -0.527 \\
\hline & 180 & 0.102 & -0.378 & -0.017 & 0.051 & 0.090 & 0.046 & -0.455 \\
\hline & 200 & -0.403 & 0.201 & -0.533 & -0.434 & -0.361 & -0.468 & 0.096 \\
\hline & 220 & -0.301 & 0.233 & -0.445 & -0.330 & -0.246 & -0.402 & 0.140 \\
\hline & 240 & -0.445 & 0.298 & -0.569 & -0.465 & -0.385 & -0.558 & 0.161 \\
\hline & 260 & -0.323 & -0.057 & -0.432 & -0.363 & -0.316 & -0.354 & -0.177 \\
\hline & 280 & -0.495 & 0.247 & -0.593 & -0.522 & -0.466 & -0.497 & 0.165 \\
\hline & 300 & $-0.804^{*}$ & 0.505 & $-0.866^{*}$ & $-0.820^{*}$ & $-0.775^{*}$ & $-0.779^{*}$ & 0.456 \\
\hline
\end{tabular}

${ }^{*},{ }^{* * *}$ indicate significance at $\mathrm{p}<0.05, \mathrm{p}<0.01$, respectively

\section{Relationship between soil moisture at anthesis and protein content and grain yield}

The relationship between the soil water content in $0-300 \mathrm{~cm}$ soil at anthesis and grain yield and protein content was determined with two polynomial (Fig. 6), and the equation of soil water content and protein yield was $\mathrm{y}_{1}=-0.0003 \mathrm{x}^{2}+0.1699 \mathrm{x}-6.9076$ $\left(\mathrm{R}^{2}=0.7200\right)$, the equation of soil water content and grain yield was $\mathrm{y}_{2}=-1.0762 \mathrm{x}^{2}+$ $648.02 x-93902\left(\mathrm{R}^{2}=0.8199\right)$ in $2012-2013$. The polynomial equation of soil moisture storage and protein yield in the 2013-2014 was $\mathrm{y}_{3}=2 \mathrm{e}-05 \mathrm{x}^{2}-0.0306 \mathrm{x}+20.892\left(\mathrm{R}^{2}=\right.$ $0.7640)$, the equation of soil water storage and grain yield was $\mathrm{y}_{4}=.-0.9216 \mathrm{x}^{2}+595.64 \mathrm{x}$ - $90716\left(\mathrm{R}^{2}=0.7782\right)$. With the increase of soil moisture at anthesis, the grain yield was increased first and then decreased, whereas, grain protein content was decreased. 


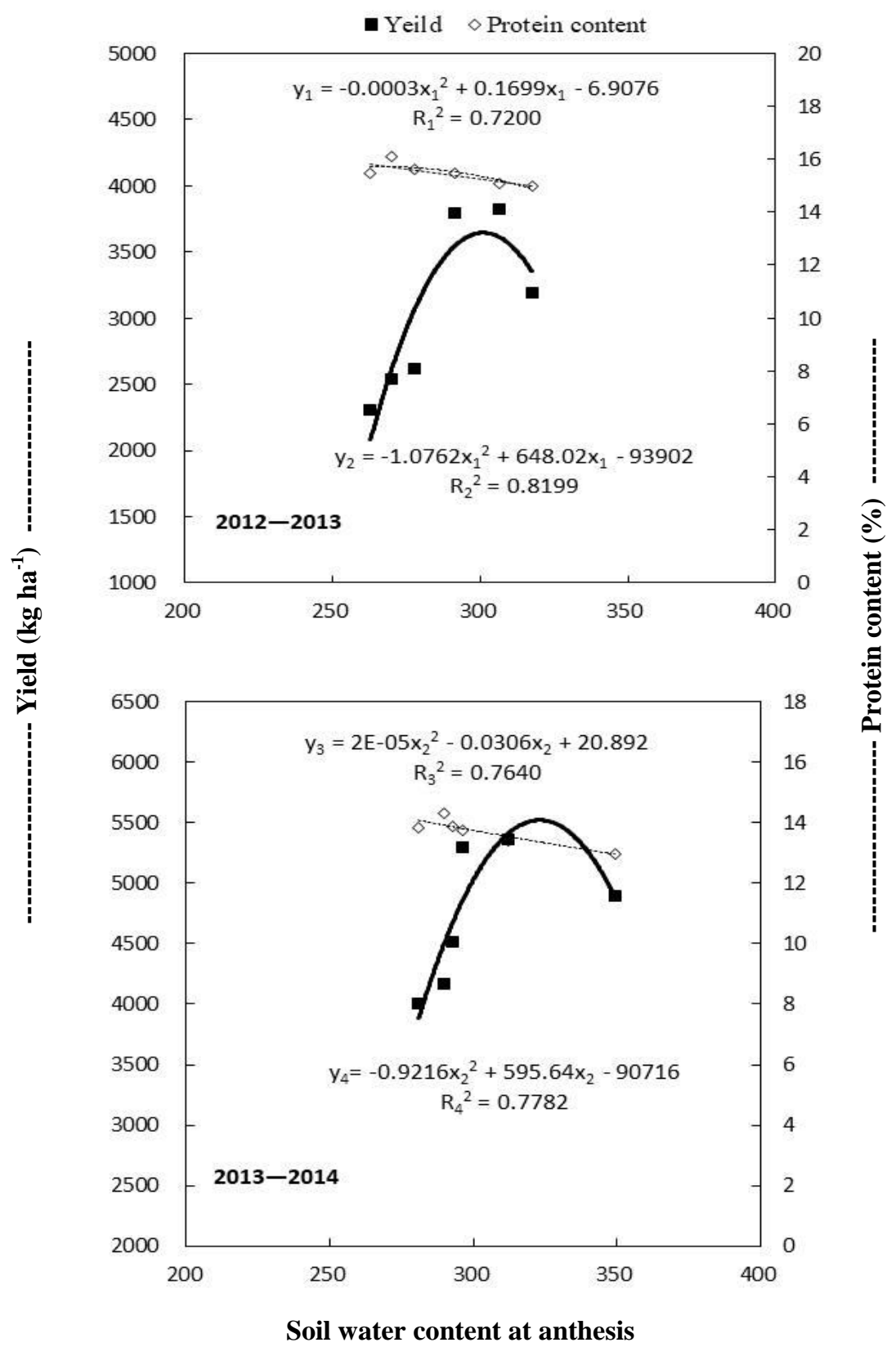

Figure 6. Correlation between soil water content and protein content ( $y_{1}$ and $\left.y_{3}\right)$, and soil water content and grain yield ( $y_{2}$ and $\left.y_{4}\right)$

\section{Discussion}

Effect of soil water storage, and yield and quality improvement under subsoiling during fallow period in dryland winter wheat

Accumulating of precipitation during the fallow period and coordinating the relationship between planting density and seeding rate is important for dryland wheat production. Present study showed that subsoiling (SS) during fallow period is conducive for the accumulation of precipitation in soil during fallow period especially during the year with less precipitation (2012-2013) and the effect of moisture storage may continue up to the flowering. Previous research also demonstrated that fallow subsoiling can 
effectively accumulate summer rainfall, and improve the soil storage capacity of winter wheat before sowing (Hou et al., 2009; Williams et al., 2006). Subsoiling increased rooting depth and also played a role in decelerating the yield stagnation under long term no tillage cultivation of wheat (Izumi et al., 2009). The subsoiling treatment and high stubble during summer fallow period in Luoyang dry zone increased soil water availability and increased yield by $5 \%$ (Su et al., 2007). Subsoiling during fallow period in the Weibei dryland increased soil water storage capacity by $21 \mathrm{~mm}$ in $0-300 \mathrm{~cm}$ soil layer before sowing, and increased yield by $5 \%$ as compared with tillage (Mao et al., 2010).

Subsoiling was proved beneficial in the Loess Plateau for the accumulation of precipitation in deep soil, with higher grain yield in years with different precipitation, and more obvious effect of water storage on increase in yield was observed in the year with less precipitation (Sun et al., 2013; Sun et al, 2018). Subsoiling not only improved the soil water storage at different growth stages but also increased the water utilization and ultimately increased yield of dryland wheat (Sun et al., 2015). In contrast, no increase in yield was observed by rotary subsoiling in winter wheat field even though the soil moisture was increased and runoff and soil erosion was reduced by rotary subsoiling (Pikul Jr. and Aase, 1999; Williams et al., 2006). Wang et al. (2009) showed that the use of subsoiling during the fallow period can increase the grain protein content and improve the quality. Zhao et al. (2012) showed that subsoiling during the fallow period reduced the proline content of the flag leaf and grains on the 5-15 d after anthesis, and the grain GS activity was increased, while the effects of grain protein content was differed with years with different precipitation, as the grain protein content was reduced in year with less precipitation by using the subsoiling during fallow period. Whereas, the use of subsoiling during fallow period is beneficial to improve grain protein content in the year with more precipitation. In summary, grain protein formation is closely related to soil moisture.

\section{Regulatory effect of planting density on yield formation of wheat}

Constructing a reasonable group structure and forming a strong seedling before winter is important for wheat production in dryland. Plant density significantly impacts the competition among plants and consequently affects the utilization of available resources including light, water, and nitrogen (Olsen et al., 2006). At high planting density, the water consumption is high at the early stage of growth which intensified the drought at the later stage and yield is reduced. On the other hand, when the seeding amount is too less, the population is less and the number of panicles is insufficient resulting in reduced yield (Zhang et al., 2016; Shi et al., 2017; Lei et al., 2017). Appropriate seeding rate can optimize the yield component and increase production. Hai et al. (2002) in the dryland wheat field in Shaanxi Province showed that when seeding rate was increased from $75 \mathrm{~kg} \mathrm{ha}^{-1}$ to $165 \mathrm{~kg} \mathrm{ha}^{-1}$ then the highest yield was achieved at $105 \mathrm{~kg} \mathrm{ha}^{-1}$. The water consumption is high at the high seeding rate, although the yield output is reduced, and the medium planting density consumes less water with the high yield output. It can be seen that increasing the seeding rate under the condition of sufficient water can increase the yield, but increasing the seeding amount under the condition of insufficient water will reduce the production to a certain extent. 


\section{Regulatory effect of planting density on protein content and protein fractions of wheat grains}

In the present study, the total protein, albumin, gliadin, glutenin content and the ratio of glutenin to gliadin were highest at planting density 190 plants $\mathrm{m}^{-2}$ and gradually decreased by increasing the planting density. After subsoiling during the fallow period, with the increase of planting density, the grain protein and component content, and the ratio of glutenin to gliadin were increased first and then decreased, and maximum protein content and protein fractions were found at the planting density of 260 plants $\mathrm{m}^{-}$ ${ }^{2}$. It may be due to the reason that at high plant population tillers group were reduced whereas nitrogen metabolism is higher in the early stage of grain filling. These observations are consistent with the findings from other researchers. Wang et al. (2014) conducted trial in the dryland of central Guanzhong area and showed that the grain protein content was first increased and then decreased with increasing the planting density in the range of $245 \times 10^{4} \mathrm{ha}^{-1}$ to $330 \times 10^{4} \mathrm{ha}^{-1}$, and was the highest at $285 \times 10^{4} \mathrm{ha}^{-}$ 1. Present results indicated that nitrogen metabolizing enzymes were highest under the medium planting density. Nitrogen metabolizing enzymes [glutamate synthase (GS), glutamate synthase (GOGAT) and glutamate pyruvate transaminase (GPT)] are involved in the primary assimilation off ammonium into glutamate and glutamine, which can be used to translocate nitrogen from source to sink (Maclaux-Daubresse et al., 2006; Nigro et al., 2013). GPT is responsible for the biosynthesis of other amino acids from the major nitrogen-carrier glutamine and thus is very important for the formation of storage protein in grain and regulation of nitrogen metabolism (Zhou et al., 2006). Higher activities of GS, GOGAT and GPT leading to higher grain protein content (Kaur et al., 2015). Nitrogen assimilation and reutilization is very important and related to grain nitrogen and nitrogen content in the aboveground part of the plant has direct effect on nitrogen yield (Nikolic et al., 2012).

In present study, the amount of nitrogen translocation and the contribution of nitrogen translocation from leaves and spike to grain were increased by increasing planting density, but the difference between planting density of 260 plants $\mathrm{m}^{-2}$ and 320 plants $\mathrm{m}^{-2}$ was not significant. In short, the adjustment of seeding rate affects the accumulation of soil moisture and plant nitrogen, thus affecting the formation of grain protein. Desai et al. (1978) showed that the grain protein content of wheat was mainly regulated by the amount of nitrogen accumulated in various organs before flowering. Xue et al. (2017) showed that under the condition of subsoiling by increasing seeding rate, the accumulation of nitrogen in various organs before anthesis was increased.

\section{Relationship between soil moisture and yield and protein accumulation in wheat}

Under the conditions of this experiment, the soil water storage during anthesis in 300 $\mathrm{cm}$ soil layer was in the range of $260-350 \mathrm{~mm}$. With the increase of soil moisture, the grain yield showed a trend of first increasing and then decreased. In 2012-2013, soil storage capacity of 0-300 $\mathrm{cm}$ at anthesis was in the range of $263-318 \mathrm{~mm}$, and grain yield was increased first and then decreased with the planting density. The soil water storage at the highest planting density $\left(320\right.$ plants $\mathrm{m}^{-2}$ ) was $306 \mathrm{~mm}$, but was $291 \mathrm{~mm}$ at the planting density of 260 plants $\mathrm{m}^{-2}$ but the difference of yield was not significant, while yield was decreased at planting density 190 plants $\mathrm{m}^{-2}$ when soil water storage was $318 \mathrm{~mm}$. This may be due to the low population density and number of spikes, and 
the insufficient number of spikes leads to a decrease in yield. At the same time, with the increase of soil moisture, the grain protein content showed a gradual decline.

Zhou et al. (2006) showed that the relative water content of soil during grain filling stage of wheat was in the range of $50 \%-80 \%$. With the increase of soil moisture, the yield was increased first and then decreased and highest yield was attained at $70 \%$ soil moisture content, whereas, the grain protein content showed a gradual decline. Zhang et al. (2006) carried out the pot experiment in which soil moisture content in the whole growth period was in the range of $50 \%-80 \%$. With the increase of soil moisture, the yield was increased first and then decreased whereas grain protein content showed a gradual decline. It can be seen that adjusting soil moisture can obtain the optimal soil moisture content with simultaneous increase in yield and grain protein content. It is shown that the optimum soil moisture content can be obtained by adjusting the soil moisture and synchronous increment of grain protein content.

In present study, in 2012-2013, under the no-tillage, the grain protein content was highest when the soil water storage was $263 \mathrm{~mm}$ (planting density 190 plants $\mathrm{m}^{-2}$ ), whereas under the subsoiling, grain protein content and yield was the highest at the planting density of 260 plants $\mathrm{m}^{-2}$ when the soil water storage was $291 \mathrm{~mm}$. In the same way, in 2013-2014 the soil water storage capacity was maximum $(296 \mathrm{~mm})$ at the planting density of 260 plants $\mathrm{m}^{-2}$ Thus, the soil moisture content was improved at planting density of 260 plants $\mathrm{m}^{-2}$ which could achieve simultaneous increase in yield and protein content.

\section{Conclusion}

The different planting density significantly affected the grain yield and protein content of dryland wheat. Under the conditions of this experiment, gliadin, glutenin, total protein content and the ratio of glutenin to gliadin were closely related with the soil water storage in 120-200 cm and 260-280 cm soil layer in the $2012-2013$ and $20-80 \mathrm{~cm}$ in the 2013-2014 at anthesis stage. The relationship between soil water storage at anthesis with grain yield and protein content indicated that albumin, globulin, gliadin and protein content were negatively related with the soil moisture content at anthesis, whereas, the grain yield was increased first and then decreased, whereas, grain protein content was decreased. The grain yield was increased by increasing the planting density from 190 to 320 plants $\mathrm{m}^{-2}$, whereas the grain protein content was maximum at 260 plants $\mathrm{m}^{-2}$ and protein content in no tillage was higher than that under subsoiling. Furthermore, the activities of glutamine synthetase (GS), glutamate synthase (GOGAT) in grain and flag leaves were also highest at 260 plants $\mathrm{m}^{-2}$. Therefore, subsoiling and optimum planting density (260 plants $\mathrm{m}^{-2}$ ) simultaneously improved the yield and protein content. The further studies might be conducted to elucidate how GS, GOGAT and GPT activities are related with the soil water content and nitrogen use efficiency at different planting density of dryland winter wheat.

Acknowledgements. The authors would like to thank anonymous reviewers for valuable input. This work was supported by the earmarked fund for China Agriculture Research System (CARS-03-01-24), the National Natural Science Foundation of China (31771727), and the National Key Technology R\&D Program of China (2015BAD23B04-2). The research project was also supported by the Shanxi Scholarship Council, China (2015-Key 4), the Shanxi Science and Technology Innovation Team Project, China (201605D131041), the Jinzhong Science and Technology Plan Project, China (Y172007-2), the 
Sanjin Scholar Support Special Funds, China, and the Special Fund for Agro-scientific Research in the Public Interest, China (201503120).

\section{REFERENCES}

[1] Bai, W. X., Li, J., Wang, Y. L., Wang, L. (2014): Effects of different tillage methods on soil water and crop yield of winter wheat-spring maize rotation region in weibei highland. - Scientia Agricultura Sinica 47(5): 880-894.

[2] Bhatt, R., Khera, K. L. (2006): Effect of tillage and mode of straw mulch application on soil erosion in the submontaneous tract of Punjab, India. - Soil Tillage Research 88: 107115 .

[3] Bhatta, M., Eskridge, K. M., Rose, D. J., Santra, D. K., Baenziger, P. S., Regassa, T. (2017): Seeding rate, genotype, and topdressed nitrogen effects on yield and agronomic characteristics of winter wheat. - Crop Science 57(2): 951-963.

[4] Desai, R. M., Bhatia, C. R. (1978): Nitrogen uptake and nitrogen harvest index in durum wheat cultivars varying in their grain protein concentration. - Euphytica 27(2): 561-566.

[5] Gaile, Z., Ruza, A., Kreita, D., Paura, L. (2017): Yield components and quality parameters of winter wheat depending on tillering coefficient. - Agronomy Research 15(1): 79-93.

[6] Hai, J. B., You, H. X., Zhang, B. J. (2002): Effects of different sowing rates an the growth and development, yield and quality of winter wheat variety Xiaoyan 503 for noodles. - Journal of Triticeae Crops 22(3): 92-94 (in Chinese).

[7] Halvorson, A., Nielsen, D., Reule, C. (2004): Nitrogen fertilization and rotation effects on no-till dryland wheat production. - Agron Journal 96: 1196-1201.

[8] Hou, X. Q., Han, Q. F., Jia, Z. K., Li, Y. P., Yang, B. P. (2009): Effects of different tillage practices in summer fallow period on soil water and crop water use efficiency in semi-arid areas. - Agricultural Research in the Arid Areas 27(5): $52-58$ (in Chinese).

[9] Izumi, Y., Yoshida, T., Iijima, M. (2009): Effects of subsoiling to the non-tilled field of wheat-soybean rotation on the root system development, water uptake, and yield. - Plant Production Science 12(3): 327-335.

[10] Kaur, B., Asthir, B., Bains, N. S. (2017): Enzymatic efficiency and genotypic differences for nitrogen assimilation in wheat. - Proceedings of the National Academy of Sciences, India Section B: Biological Sciences 87(3): 985-995.

[11] Lei, M. M., Sun, M., Gao, Z. Q., Wang, P. R., Ren, A. X., Xue, L. Z., Yang, Z. P. (2017): Effect of subsoiling during the fallow period and timely sowing on water storage and wheat yield of dryland. - Scientia Agricultura Sinica 50(15): 2904-2915.

[12] Li, J., Wang, L., Ren, L. K., Liu, Y. H., Cao, W. X., Dai, T. B. (2010): Effect of sowing date, density and nitrogen management on grain yield and quality of winter wheat Laimai 2. - Journal of Triticeae Crops 30(2): 303-308 (in Chinese).

[13] Li, S. X. (2002): Ways and strategies for increasing fertilizer nitrogen efficiency in dryland soil. - Acta Pedologica Sinica 39 (Suppl.): 56-75 (In Chinese).

[14] Liao, Y. C., Han, S. M., Wen, X. X. (2002): Soil water wontent and crop yield effects of mechanized conservative tillage-cultivation system for dryland winter wheat in the loess tableland. - Transactions of the CSAE 18(4): 68-71 (in Chinese).

[15] Lin, C. C., Kao, C. H. (1996): Disturbed ammonium assimilation in associated with growth inhibition of roots in rice seedlings caused by NaCl. - Plant Growth Regulation 18(3): 233-238.

[16] Liu, P., Guo, W. S., Xu, Y. M., Feng, C. N., Zhu, X. K., Peng, Y. X. (2006): Effect of planting density on grain yield and quality of weak-gluten and medium-gluten wheat. Journal of Triticeae Crops 26(5): 117-121 (in Chinese). 
[17] Lloveras, J., Manent, J., Viudas, J., López, A., Santiveri. P. (2004): Planting density influence on yield and yield components of irrigated winter wheat in a Mediterranean climate. - Agronomy Journal 96: 1258-1265.

[18] Lu, B. B., Yuan, Y. Z., Zhang, C. F., Ou, J. Q., Zhou, W., Lin, Q. H. (2005): Modulation of key enzymes involved in ammonium assimilation and carbon metabolism by low temperature in rice (Oryza sativa L.) roots. - Plant Science 169(2): 295-302.

[19] Ma, D. Y., Guo, T. C., Cha, F. N., Wang, C. Y., Zhu, Y. J., Wang, Y. H. (2007): Effects of planting density on activities of nitrogen metabolism enzymes in flag leaves and grain protein content in winter wheat with two spike types. - Acta Agronomica Sinica 33(3): 514-517.

[20] Ma, W. Q., Zhang, F. S., Zhang, W. F. (2005): Fertilizer production and consumption and the resources, environment, food security and sustainable development in China. Resource Science 27(3): 33-40.

[21] Mao, H. L., Li, J., Jia, Z. K., Wang, L. (2010): Soil water conservation effect, yield and income increment of conservation tillage measures on dryland wheat field. - Transactions of the CSAE 26(8): 44-51 (in Chinese).

[22] Masclaux-Daubresse, C., Reisdorf-Cren, M., Pageau, K., Lelandais, M., Grandjean, O., Kronenberger, J., Valadier, M. H., Feraud, M., Jouglet, T., Suzuki, A. (2006): Glutamine synthetase-glutamate synthase pathway and glutamate dehydrogenase play distinct roles in the sink-source nitrogen cycle in tobacco. - Plant Physiology 140(2): 444-456.

[23] Nigro, D., Gu, Y. Q., Huo, N., Marcotuli, I., Blanco, A., Gadaleta, A., Anderson, O. D. (2013): Structural analysis of the wheat genes encoding NADH-dependent glutamine-2oxoglutarate amidotransferases and correlation with grain protein content. - PloS ONE, 8(9): e73751.

[24] Nikolic, O., Zivanovic, T., Jelic, M., Djalovic, I. (2012): Interrelationships between grain nitrogen content and other indicators of nitrogen accumulation and utilization efficiency in wheat plants. - Chilean Journal of Agricultural Research 72:111-116.

[25] Olsen, J., Kristensen, L., Weiner, J. (2006): Influence of sowing density and spatial pattern of spring wheat (Triticum aestivum) on the suppression of different weed species. - Weed Biology and Management 6: 165-173. doi: 10.1111/j.1445-6664.2006.00210.x.

[26] Pikul Jr, J. L., Aase, J. K. (1999): Wheat response and residual soil properties following subsoiling of a sandy loam in eastern Montana. - Soil and Tillage Research 51(1-2): 6170.

[27] Rapp, M., Lein, V., Lacoudre, F., Lafferty, J., Müller, E., Vida, G., Bozhanova, V., Ibraliu, A., Thorwarth, P., Piepho, H. P., Leiser, W. L. (2018): Simultaneous improvement of grain yield and protein content in durum wheat by different phenotypic indices and genomic selection. - Theoretical and Applied Genetics 131(6): 1315-1329.

[28] Schillinger, W. F. (2005): Tillage method and sowing rate relations for dryland spring wheat, barley, and oat. - Crop Science 45: 2636-2643.

[29] Shi, X. F., Chou, S. Y., Shi, Z. L., Xie, F. L., Gao, W., Song, L. H. (2017): Effect of sowing date and sowing amount on population traits and yield of winter wheat cultivar Yaomai 16. - Journal of Triticeae Crops 37(2): 1-9 (in Chinese).

[30] Sparkes, D. L., Holme, S. J., Gaju, O. (2006): Does light quality initiate tiller death in wheat?. - European Journal of Agronomy 24: 212-217.

[31] Su, Z. Y., Zhang, J. S., Wu, W. L., Cai, D. X., Lv, J. J., Jiang, G. H., Huang, J., Cao, J., Hartmann, R., Gabriels, D. (2007): Effects of conservation tillage practices on winter wheat water-use efficiency and crop yield on the Loess Plateau, China. - Agricultural Water Management 87: 307-314.

[32] Sun, M., Gao, A. Z. Q., Ren, X., Deng, Y., Zhao, W. F., Zhao, H. M., Yang, Z. P., He, L. H., Zong, Y. Z. (2015): Contribution of subsoiling in fallow period and nitrogen fertilizer to the soil-water balance and grain yield of dryland wheat. - International Journal of Agriculture and Biology 17: 175-180. 
[33] Sun, M., Gao, Z., Zhao, W., Deng, L., Deng, Y., Zhao, H., Ren, A., Li, G., Yang, Z., (2013): Effect of subsoiling in fallow period on soil water storage and grain protein accumulation of dryland wheat and its regulatory effect by nitrogen application. - PLoS ONE 8(10): e75191. https://doi.org/10.1371/journal.pone.0075191.

[34] Sun, M., Ge, X. M., Gao, Z. Q., Ren, A. X., Deng, Y., Zhao, W. F., Zhao, H. M. (2014): Relationship between water storage conservation in fallow period and grains protein formation in dryland wheat in different precipitation years. - Scientia Agricultura Sinica 47(9): 1692-1704 (in Chinese).

[35] Sun, M., Ren, A. X., Gao, Z. Q., Wang, P. R., Mo, F., Xue, L. Z., Lei, M. M. (2018): Long-term evaluation of tillage methods in fallow season for soil water storage, wheat yield and water use efficiency in semiarid southeast of the Loess Plateau. - Field Crops Research 218: 24-32.

[36] Wang, J., Lin, Q., Ni, Y. J., Liu, Y. G. (2009): Effects of different conservation tillage patterns on grain quality of winter wheat. - Journal of Triticeae Crops 29(5): 881-884 (in Chinese).

[37] Wang, N., Wang, J. M., Yao, G. P., Meng, X., Jiao, J. L. (2014): The effect of different sowing date and rate on yield and quality of the wheat variety "Jiumai2" . - Chinese Agricultural Science Bulletin 30(21): 80-84 (in Chinese).

[38] Wang, Y. H., Yao, Y. Q., Lyu, J. J., Huang, J. T., Zhang, J. (2004): Ecological effect of subsoiling high stubble on the winter wheat in sloping land of western Henan. - Chinese Journal of Eco-Agriculture 12(2): 146-148 (in Chinese).

[39] Williams, J. D., Wuest, S. B., Schillinger, W. F., Gollany, H. T. (2006): Rotary subsoiling newly planted winter wheat fields to improve infiltration in frozen soil. - Soil and Tillage Research 86(2): 141-151.

[40] Wu, L. H., Tao, Q. N. (2003): Effects of amino acid-N on rice nitrogen nutrition and its mechanism. - Acta Pedoogical Sinica 37: 464-473 (in Chinese).

[41] Xie, Q., Mayes, S., Sparkes, D. L. (2016): Optimizing tiller production and survival for grain yield improvement in a bread wheat $\times$ spelt mapping population. - Annals of Botany 117(1): 51-66.

[42] Xie, Z. J., Jiang, D., Can, W. X., Dai, T. B., Jing, Q. (2003): Effects of post anthesis soil water status on the activities of key regulatory enzymes of starch and protein accumulation in wheat grains. - Journal Plant Physiologica Molecular Biology 29: 309316.

[43] Xu, Z. Z., Yu, Z. W., Wang, D., Zhang, Y. L. (2003): Effect of irrigation conditions on protein composition accumulation of grain and its quality in winter wheat. - Acta Agronomica Sinica 29(5): 682-687 (in Chinese).

[44] Xue, L. Z., Sun, M., Gao, Z. Q., Ren, A. X., Lei, M. M., Yang, Z. P. (2017): Effects of incremental planting density under sub-soiling during the fallow period on nitrogen absorption and utilization, yield and grain proteincontent in dryland wheat. - Scientia Agricultura Sinica 50(13): 2451-2462.

[45] Zecevic, V., Boskovic, J., Knezevic, D., Micanovic, D. (2014): Effect of planting density on grain quality of winter wheat. - Chilean journal of Agricultural Research 74(1): 23-28.

[46] Zhang, M. M., Dong, B. D., Qiao, Y. Z., Zhao, H., Liu, M. Y., Chen, Q. Q., Yang, H., Zheng, X. (2016): Effects of sowing date and planting density on growth, yield and water use efficiency of 'Xiaoyan 60'wheat under rainfed condition. - Chinese Journal of EcoAgriculture 24(8): 1095-1102 (in Chinese).

[47] Zhang, Y. F., Yang, W. D., Bai, J. J., Wang, D. C., Niu, B., Feng, M. C. (2006): Coordinated variation of yield and grain protein content in winter wheat and strategies of irrigation and fertilization. - Scientia Agricultura Sinica 39(12): 2449-2458 (in Chinese).

[48] Zhang, Y., Peng, B. Z., Gao, X., Yang, H. (2004): Degradation of soil properties due to erosion on sloping land in southern Jiangsu province, China. - Pedosphoere 14: 17-26.

[49] Zhang, Z. X., Liu, F. L., Zhang, B. J., Zhang, Z. M., Li, N., Lv, B. (2016): Interactive effects of fertilizer and planting density on photosynthesis characteristics of flag leaf, 
yield and quality of Pubing 151. - Journal of Triticeae Crops 36(8): 1069-1075 (in Chinese).

[50] Zhao, H. M., Gao, Z. Q., Sun, M., Zhao, W. F., Li, Q., Deng, Y., Yang, Z. P. (2012): Effect of tillage in fallow period on soil water, post-anthesis proline accumulation and grains protein accumulation in dryland wheat. - Scientia Agricultura Sinica 45(22): 45744586 (in Chinese).

[51] Zhou, Q., Jiang, D., Dai, T., Jing, Q., Cao, W. (2006): Regulation of starch and protein synthesis in wheat grains by feeding sucrose and glutamine to detached ears cultured in vitro. - Plant Growth Regulation 48(3): 247-259.

[52] Zhou, X. G., Chen, J. P., Liu, A. N., Huang, Z. D. (2006): Effects of the different soil moistures on physiological characteristics, yield and quality of winter wheat during the intergrowth stage under the winter wheat and cotton relay intercropping. - Transactions of the CSAE 22 (11): 22-26 (in Chinese). 